\title{
Morphology of water-based housing in Mekong delta, Vietnam
}

\author{
Thi Hong Hanh $\mathrm{Vu}^{1, *}$ and Viet Duong ${ }^{1}$ \\ ${ }^{1}$ University of Architecture Ho Chi Minh City, 196 Pasteur, District 1, Ho Chi Minh City, Vietnam
}

\begin{abstract}
A long time ago, houses along and on the water have been distinctive elements of the water-based Mekong Delta. Over a long history of development, these morphological settlements have been deteriorated due to environmental, economic, and cultural changes from water to mainland, resulted in the reductions of water-based communities and architectural deterioration. This research is aimed to analyze the distinguishing values of those housing types/communities in 5 chosen popular water-based settlements in Mekong Delta region to give positive recommendations for further changes.
\end{abstract}

\section{Introduction}

Mekong Delta is located in the South of Vietnam, downstream of the Mekong River. This is a nutrious plain with dense water channels. People here have chosen their settlements to be near, in order of priority: markets - rivers - friends -roads/streets/routes - and farmlands (Nhất cận thị, nhị cận giang, tam cận lân, tứ cận lộ, ngũ cận điền). When the population increased, they started to move inward the land; as a result, their living culture have gradually changed, so have their houses [1-3].

Over long history of exploitation, the local inhabitants and migrants from other parts of Vietnam and nearby countries have turned this Mekong delta to a rich and distinctive society with diverse ethnic communities, cultures and beliefs, living harmoniously together. Their settlements have desmontrated identifiable water-based living environments which cannot find else where [4-9].

The current research is to analyse the distinctive moephological values of these settlements. These findings help strengthen the scientific bases for further appropriate solutions for these values under threats of urbanization, cultural and climate changes that have been noticed to have much neativeaffects on these values.

In order to achieve this aim, the research is:

- To review the history of water - based settlements in Mekong delta in order to understand and identify places where these living culture have been historically strong; typologies

- To develop a framework to analyse the morphological characteristics of housing

\footnotetext{
* Corresponding author: hanh.vuthihong@uah.edu.vn
} 
To carried out a pilot survey to briefly identify places where water-based housing typologies still dense and strong; from that, to conduct an actual survey to collect data for the morphological analysis of the selected areas;

To do the analysis and discuss how these characters should be responded

\section{Literature review}

The literature review is to facilitate the background and bases for the research objectives; therefore, include two parts: (1) History of Mekong delta human settlement, (2) Relevant literature on Building morphological framework of analysis, focusing on water-based housing typologies.

\subsection{History human settlement in Mekong delta [6,8-14]}

Being at the downstream of Mekong River, Mekong delta is a nutrious plain of 13 provinces in the Southern of Vietnam. With its very dense water network, this is homes of many ethnic communities of Kinh, Khmer, and Cham who have practiced their own religions and beliefs dated back 300 years ago.

Human settlements in Mekong Delta for a long time have witnessed the dominations of waterway in transport, farming, and climatic appropriations. In 1689 General Comander Nguyen Huu Canh, appointed by Nguyen Dynasty started the Southward exploitation, including this delta. From the 7 th century, this southern land has become 'dream land for farming' of many migrants from the North and Central Vietnam; and later of the Chinese (mainly from Guangdong, Fujian and Hainan); Not until French colonial period in the $19^{\text {th }}$ century, industries were developed; however, still focused on aquaculture [12].

Using boats for all kinds of movements, commercial and daily living activities, many settlements in Mekong delta have been developed at intersections of water channels, and waterways have been routes connecting different settlements together. Since the late $19^{\text {th }}$ century, roads were more developed, reducing the reliability on water of many communities. Today, water is no longer 'dream homes' of many water-based communities members, and they tend to move in land whenever they could afford $[1,15,16]$.

\subsection{Morphological framework of analysis, focusing on water-based housing typologies [14,17-19]}

Morphological approach provides systematic understanding of a building from composing elements such as the location, asscess, plot, density, setback, building form, style and architectural details and finishing. Simon Unwin, A. Demkin và James A. LaGro considered building with its layers is inner base, to which the outsiders such as natural, social, economic, historic, political, technical, and personal conditions place strong affects on the forms and transformations of buildings and surrounding settlements [17-20].

Table 1. Elements influence the foundation and transformations of water-based houses in 4 research sites [1].

\begin{tabular}{|l|l|l|l|l|l|}
\hline & $\begin{array}{l}\text { Cai Be floating } \\
\text { market }\end{array}$ & $\begin{array}{l}\text { Cai Rang floating } \\
\text { market }\end{array}$ & Camau market & $\begin{array}{l}\text { Chau Doc floating } \\
\text { village }\end{array}$ \\
\hline $\begin{array}{l}\text { Natural } \\
\text { conditions }\end{array}$ & $\begin{array}{l}\text { Similar climatic conditions and locations of settlements (on and along water } \\
\text { channels) }\end{array}$ & $\begin{array}{l}\text { Located in Tien } \\
\text { River, bordered of } \\
\text { three provinces: }\end{array}$ & $\begin{array}{l}\text { Located in Can } \\
\text { Tho River, middle }\end{array}$ & $\begin{array}{l}\text { Located in Ca } \\
\text { Mau River, } \\
\text { intersection of }\end{array}$ & $\begin{array}{l}\text { Located in the } \\
\text { upstream of Hau River, }\end{array}$ \\
\hline
\end{tabular}




\begin{tabular}{|l|l|l|l|l|}
\hline & $\begin{array}{l}\text { Tien Giang, Vinh } \\
\text { Long, and Ben Tre }\end{array}$ & $\begin{array}{l}\text { section of Hau } \\
\text { River }\end{array}$ & $\begin{array}{l}\text { 04 rivers and } \\
\text { canals }\end{array}$ & $\begin{array}{l}\text { intersected with Vinh } \\
\text { Te canal }\end{array}$ \\
\hline $\begin{array}{l}\text { Social } \\
\text { conditions }\end{array}$ & $\begin{array}{l}\text { Having many ethnic communities: Kinh, Khmer, Cham, and Chinese; pacticing } \\
\text { different religions and beliefs, experiencing different historic movements of Mekong }\end{array}$ \\
\hline $\begin{array}{l}\text { Cultural } \\
\text { conditions }\end{array}$ & $\begin{array}{l}\text { Culture of adaptations to natural conditions which dominated by water } \\
\text { Social Behavioral Culture }\end{array}$ \\
\hline $\begin{array}{l}\text { Economic } \\
\text { conditions }\end{array}$ & $\begin{array}{l}\text { Economic centres of Mekong, historically and } \\
\text { contemporarily }\end{array}$ & $\begin{array}{l}\text { Fishing and farming on } \\
\text { floats/water }\end{array}$ \\
\hline $\begin{array}{l}\text { Building } \\
\text { techniques }\end{array}$ & $\begin{array}{l}\text { Inherited building techniques from the North and Central of Vietnam, with } \\
\text { modifications to adapt to "water, climatic conditions and available building materials; } \\
\text { simplifier and less detailed }\end{array}$ \\
\cline { 2 - 4 } & $\begin{array}{l}\text { Less affected by seasonal flood (annually) } \\
\text { Adaptive techniques to } \\
\text { deal with flood and } \\
\text { water-related matters }\end{array}$ \\
\hline
\end{tabular}

\section{Materials and methods}

\subsection{Research Site sellection}

As Mekong delta is vass, the research could only study some areas which somehow typical:

Criteria to shoose research site/case studies of water-based settlements/houses

- $\quad$ History of development

- $\quad$ The density of building distributions

- $\quad$ Relationship with water: activities that based on water from living, farming, trading, and so on

Sites Sellection procedure:

- $\quad$ Based on the satellite map, initially identify sites that have dense building footprints, focussing on areas on/near intersections of water channles

- Review the history to understand the history of each sites

- Carried out a pilot survey to briefly understand and to evaluate the level of representatives of the sites for certain housing/settlement typologies/morphologies

\subsection{Methods of collecting data}

Depending on different sources of information which are both qualitative and quatitative, either secondary or primary data, different methods of collecting are identified, applied in both pilot and actual surveys.

Table 2. Pilot and actual survey.

\begin{tabular}{|c|c|c|}
\hline Information & Pilot survey & Actual survey \\
\hline $\begin{array}{l}\text { Spatial morphologies and } \\
\text { building morphologies (the } \\
\text { transformations) } \\
\text { Affecting issues such as } \\
\text { urbanization, climate changes, }\end{array}$ & $\begin{array}{l}\text { - Review secondary } \\
\text { data: maps, books, } \\
\text { literature; } \\
\text { - Self observations, } \\
\text { records (photo, sketch, } \\
\text { video, ...) }\end{array}$ & $\begin{array}{l}\text { - Review secondary data: maps, books, } \\
\text { literature; } \\
\text { - Self observations, records (photo, sketch, } \\
\text { video, ...); } \\
\text { - Interview people: house's owners, } \\
\text { neighbours. }\end{array}$ \\
\hline $\begin{array}{l}\text { Spatial organization of different } \\
\text { water-based houses and } \\
\text { surroundings }\end{array}$ & & $\begin{array}{l}\text { - Interview people: house's owners, } \\
\text { neighbours. }\end{array}$ \\
\hline $\begin{array}{l}\text { Ways people live, daily activities, } \\
\text { and relationships with water }\end{array}$ & & $\begin{array}{l}\text { - Self observations, records (photo, sketch, } \\
\text { video, ...); } \\
\text { - Interview people: house's owners, } \\
\text { neighbours. }\end{array}$ \\
\hline
\end{tabular}




\section{Results}

\subsection{General characteristics of water-based settlements in Mekong Delta, Vietnam}

In Mekong delta, "Water" is not only for transports but provides ease and oppotunities to aquaculture activities, and appropriate climatic conditions for living. Therefore, most of settlements here were originally based on water, particularly where:

- Intersections of water channels: These are hubs of transports where lots of aquacutural producrts and, industrial and domestic goods are gathered and distributed to other places using water channels , such as Ngã Bảy floating market (Phụng Hiệp - Hậu Giang), Ngã Năm (intersection of 5 rivers) in Sóc Trăng, Cà Mau market in Ca Mau.

- Intersections of water channels and roads: with the advantages of both water and road transport, such as CáiRăng and CáiBè floating markets.

- Along the water channels, islands, where water flows are quite stable and understandable: these areas are suitable for commercial, exchange and aquacultural activities; popularly concentrated along Tiền and Hậu Rivers: ChâuĐốc floating village, Long Xuyên floating market.

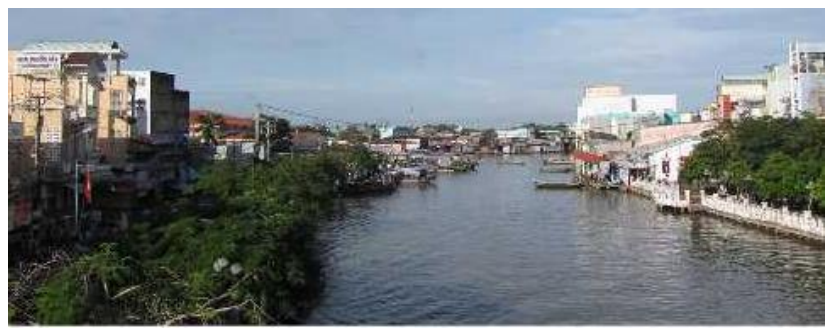

Houses at Camau Market, an intersection of 04 rivers

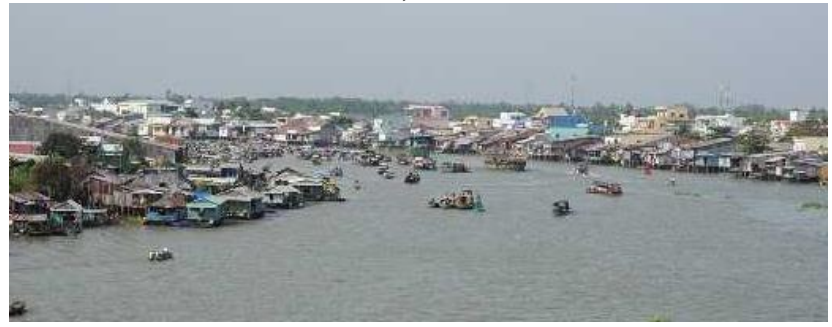

Houses at Cai Rang Market, intersection of water channels and road

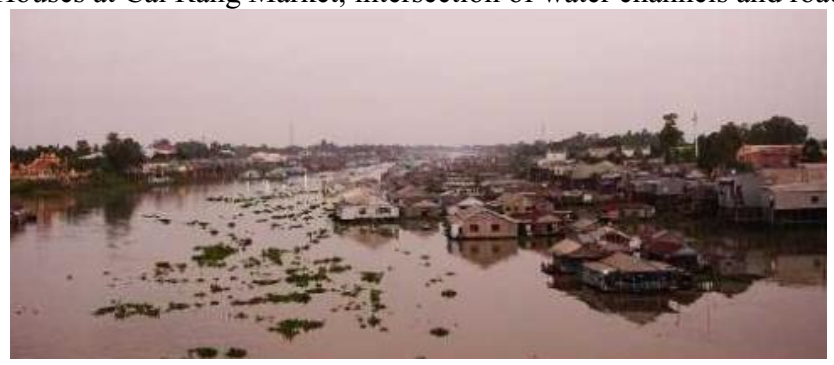

Houses at Chau Doc floating village (along water channel)

Fig. 1. Current houses on/along canals at some popular places in Mekong Delta, Vietnam (Source: Authors, survey 2016). 
To adap to topographical and geographical conditions over centuries, houses at Mekong delta have been diversified following the differentiations of the ground floor structures, including:(a) houses on the ground; (b) Houses on stilts; (c) Houses with half on stilts and half on the ground; and (d) floating houses, and (e) houseboat (Figure 2). In this research, type a is not analysed.

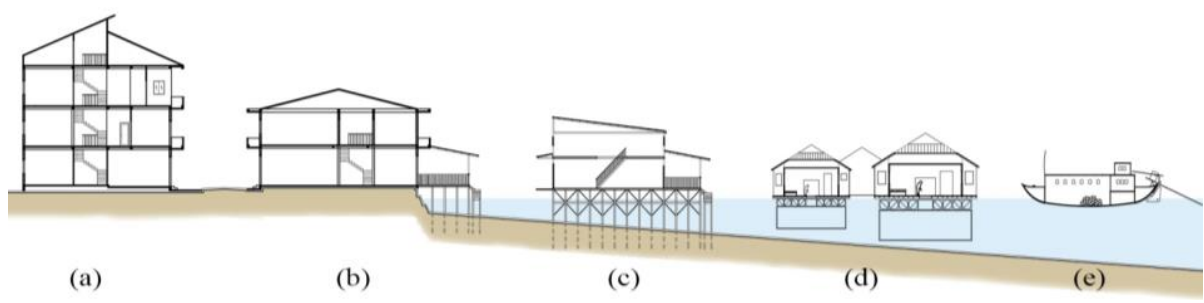

Fig. 2. Housing typologies in Mekong delta according the the ground floor structures(Source:

Authors, 2016).

\subsection{Morphological characteristics of water-based houses in Mekong delta}

Like any building's design principles, the spatial organization of water-based houses are based upon the main functional spaces, including:

(1) Communication spaces with veriety of activities such as trading, services, or productive activities; these spaces normally face to the water or road; and

(2) Spaces for more local and traditional in Mekong such as trading on water (floating markets), on - land trading/commercial activities (Vietnamese traditional market), and floating aquaculture (houseboat, floating village).

These typical spaces are, according to different water-relate housing typologies mentioned as b,c,d,e in section 4.1, diversified as followings:

\subsubsection{Houseboat}

Being the main mode of transport of people living in Mekong delta for along time, boats are combinations of living, product storage and place for doing businesses to earn their living. Boats are made from steel and/or wood, and include two main spaces:

Lower floor: mainly for storing food and agricultural products, only small area here is for living. The entire floor includes: (1) storage, (2) bedroom and kitchen, (3) technical room, (4) water tank, (5) toilet, and (6) boat front. The kitchen is quite flexible and movable where stow is portable and can be stored if not in use.

Upper floor:locally named "mui", the front (7) is for trading activities, the back (8) is smaller and used for public welcoming, resting and controlling the boat. This area has wooden or tole roof which can be removed when necessary.

A boat house should stay at a floating market from 5 to 7 days in order to sell out everything needed. Then it has to move up to hundreds of kilometers on water to nearby places/ provinces to buy/collect enough goods before going back to the floating market again. Boat houses are always chained together on the middle of the water/river to avoid strong winds and sturbulant waves. 

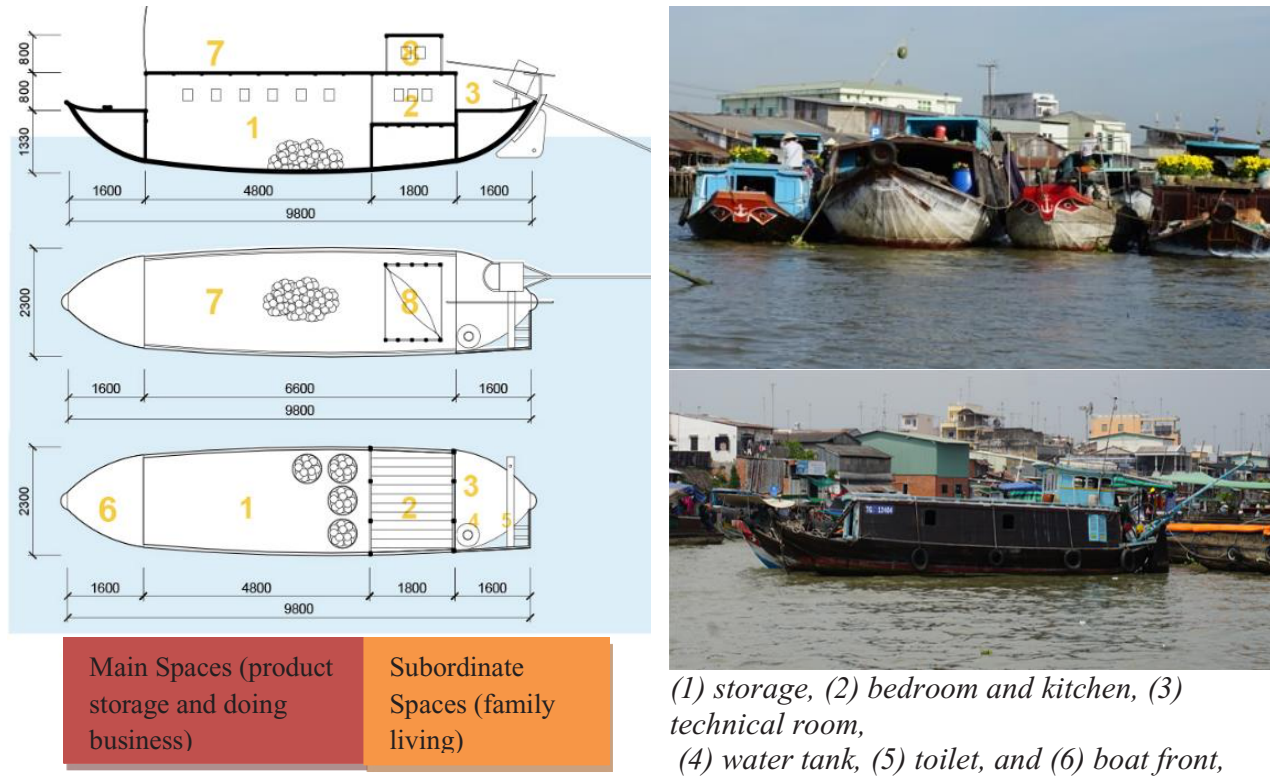

(1) storage, (2) bedroom and kitchen, (3) technical room,

(4) water tank, (5) toilet, and (6) boat front,

(7) the front are, (8) the back

Fig. 3. Houseboat at Mekong - 02 the main functional spaces (Source: Authors, 2016).

\subsubsection{Floating house}

Floating house or sometimes called house on a float is similar to houseboat, however,not moving as houseboat, and on a more flattern and wider floats made by wood or steel. In Chau Doc floating village, these housing typologies attach to a fish farm. They also float along/nearby floating markets to serve needs of surrounding communities such as gas supply, grocery, machinery repair, and so on (Fig. 4).
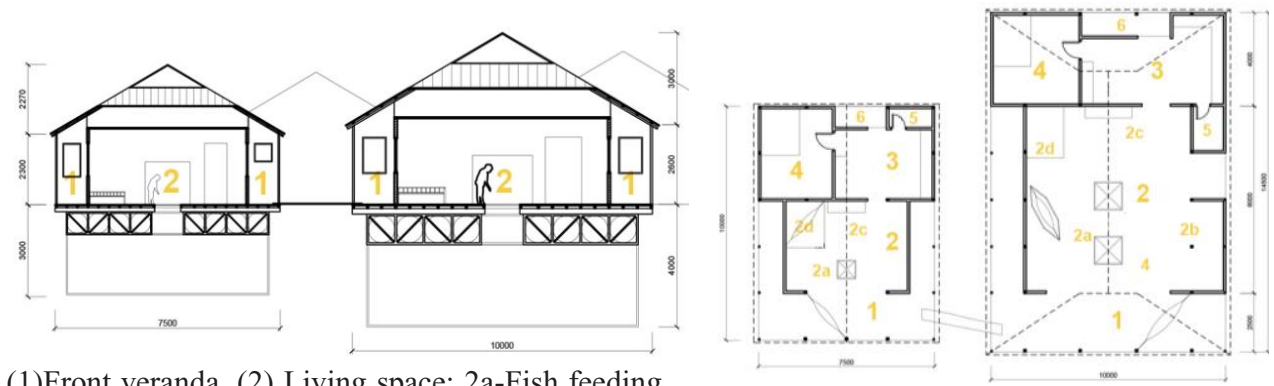

(1)Front veranda, (2) Living space: 2a-Fish feeding, 2b-Fish's food precessing zone, 2c-Worship table, 2d- Guest bed, (3) Kitchen, (4) Bedroom, (5) toilet,

(6) Back veranda
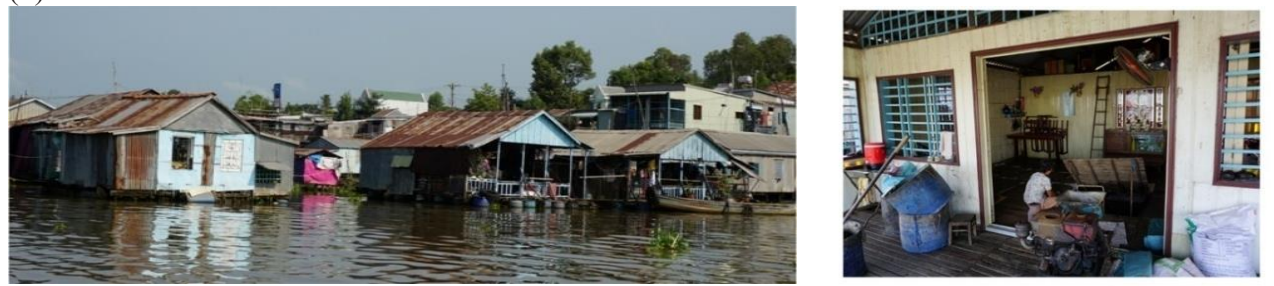

Fig. 4. House on float at Chau Doc fishing village- Mekong Delta (Source: Authors, 2016). 


\subsubsection{House on stilts}

This is the most popular type of housing in Mekong delta. Stilts made from timber or concrete are piled to the river base. It could have 1, 1.5, or 2 floors with either steel, timber or concrete structure, using light materials such as tole, leaves, or brick for walls and spatial dividers; tole roof. This type of houses has two fronts: one faces the water/river and the other one face roads. There are some houses even have both fronts facing the water. For these ones, there must be bridges made from either wood or bamboo the connect it to the land nearby.

Regarding the spatial organization of this type of house, depending on whether it is for residential only or combined with productive or trading activities, the spatial layouts are slightly different.

- Residential only house: normally has 02 main spaces: front area and back area

- Front area: also the main area which includes (in order from outside to inside) the veranda, living room/space and ancestors worship space, bedroom.

- Back area: the suppoting area which includes veriety of spaces such asguest space and dining space, Tao God's table, kitchen, storage, toilet, wet area with water tank. There might be a bedroom here too; and only close friends and family's membes are welcome to the back area of the house.

Residential combined with commercial/productive activities: this type of house normally has 2 floors with or without a mezzanine, some typical characteristics as followings:

- Ground floor: mainly for business including spaces for guest welcoming, trading, (ancestor) worshiping, storage, a flatform for goods loading and tranfering toward the river; there are smaller area on this floor for kitchen, dining, and toilet.

○ First floor or mezzanine: privately for the owners and their family members, with a small storage, bedrooms and toilet.

(1) living space,(2) worship table, (3)storage, (4) kitchen, (5) toilet, (6) back veranda, (7) storage, $(8,9)$ bedroom

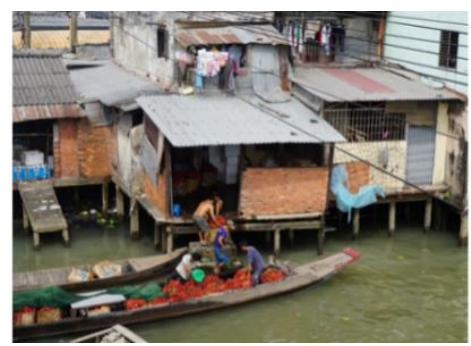

Houses on stilts in Mekong delta with the front face water (left) and face road

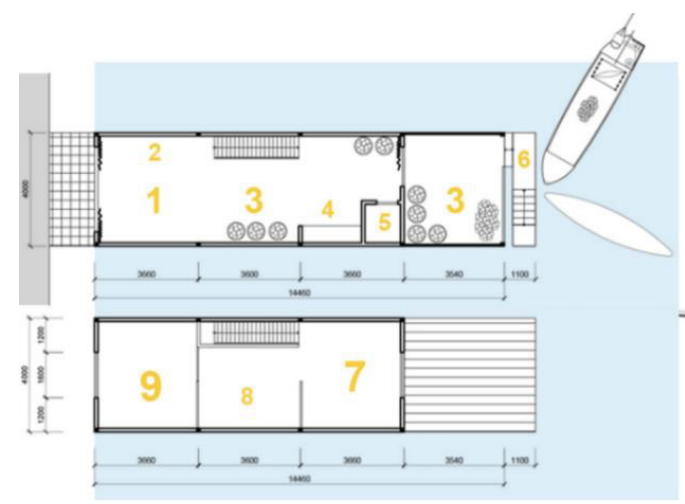

(right)
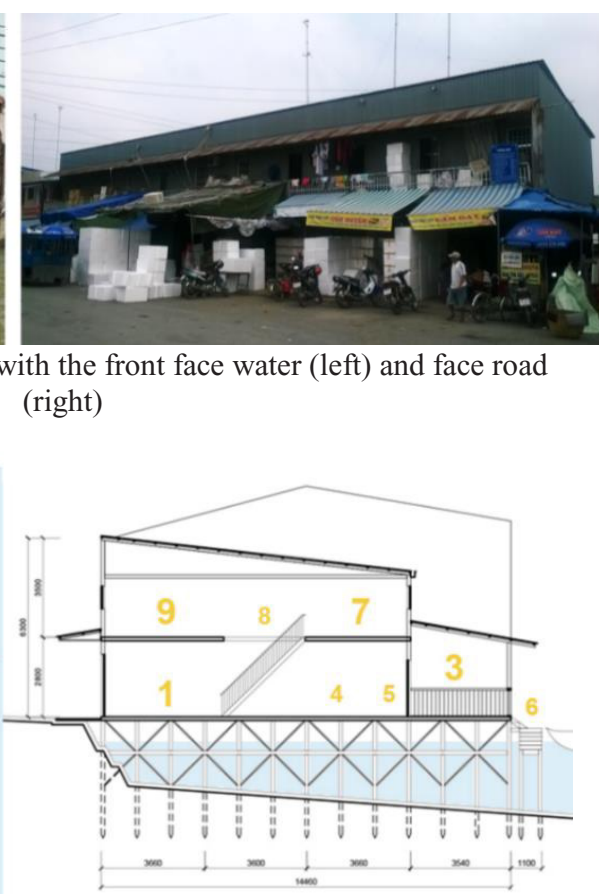

Fig. 5. Spatial organization of house on stilts in Mekong Delta (Source: Authors, 2016). 


\subsubsection{House partly on gound and on water}

This house is devided into two main parts: the main and most important one is on the ground and built with more permenant materials like brick or concrete; the other less impotant part is expanded to the water and normally built with temporary materilas like tole, leaves.

The interior spaces are organized depending on the functions of the houses which are either pure residential or residential with businesses:

- The residential only house: the interior is similar to houses on stilts if it has one floor. If the house has a mezzanine or more than 2 floors, the spatial organization is as explained below:

- Ground floor: divided into two parts

- The front part: including a veranda, guest welcoming, worshiping.

- $\quad$ The back part: kitchen, dining, Tao God worship table, storage, toilet, wet area, water tank; close friends are also welcome to this part of the house.

- The upper floor(s) is/are for family members' sharing spaces including family living rooms, bedrooms, storages, and toilets.

- House for living and doing business includes main spaces as followings:

- Ground floor: most of spaces are for doing family's business including guest welcoming space, worship place, goods storage, a goods/products loading/unloading flatform, storage; there is only a small area for kitchen, dining, and toilet here. There might be a supporting area expanded to the water for water-based businesses as well.

$\circ \quad$ Upper floors are for family's member with shared space, bedrooms, toilets and storage.

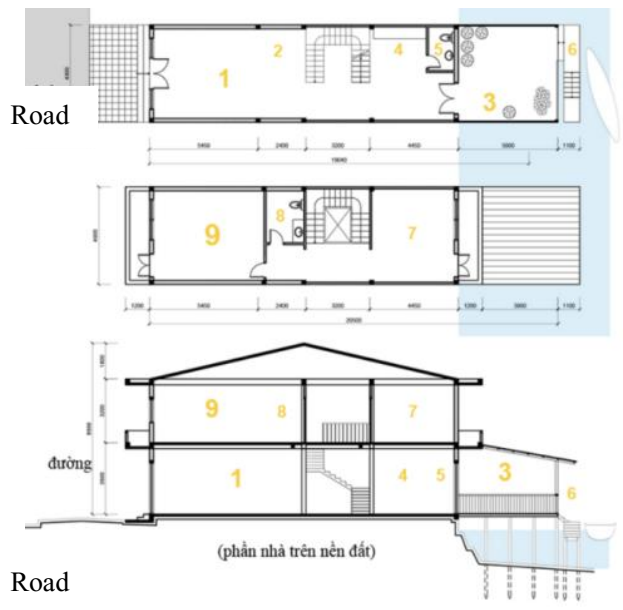

Part of the houses on ground

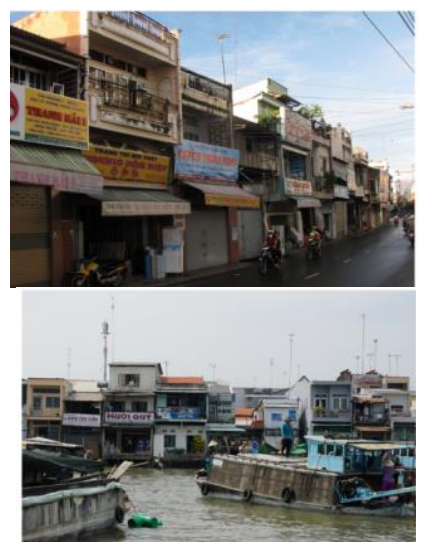

Houses with a part on water and a part facing road (1) living space,(2) worship table, (3)storage, (4) kitchen, (5) toilet, (6) back veranda, $(7,9)$ bedroom, (8) toilet

Fig. 6. Spatial organization of houses with a part on water/stilts in Mekong Delta (Source: Authors, 2016).

\subsection{Distributions of typical housing typologies in Mekong delta}

These three types of housing located along the rivers, characterized by groups/ communities represented the relationships between houses, houses with water and history of development:

- Group created/expanded by a family when their members increase.

- $\quad$ Group created by close relative and friends 
- Group created by big long houses that are divided to sell, or to rent some parts that face water or road; the owners normally do not live here.

Some characteristics of typical goups:

Group (a) boat houses: gathered by 3 to 5 boats,stably chained in the middle of the river to protect one another from strong winds and waves (at night time). In day time, they could flexibly go anywhere for their own businesses which are trading and transporting.

Group (b) houses on stilts: created either by an extended family or group of families who have the same businesses that attached to water at/near the floating markets or villages . . They use bamboo/wood 'bridge', actually a small wood/timber plate, long enough, to connect their house with the ground/land.

Group (c) houses on stilts ad partly on stilts:porpularly seen along sides of the rivers, including a series of long narrow houses, with one part on the water and the other part on the ground; business activities like trading and goods transferring are happened both fronts of the house: water front and road front.

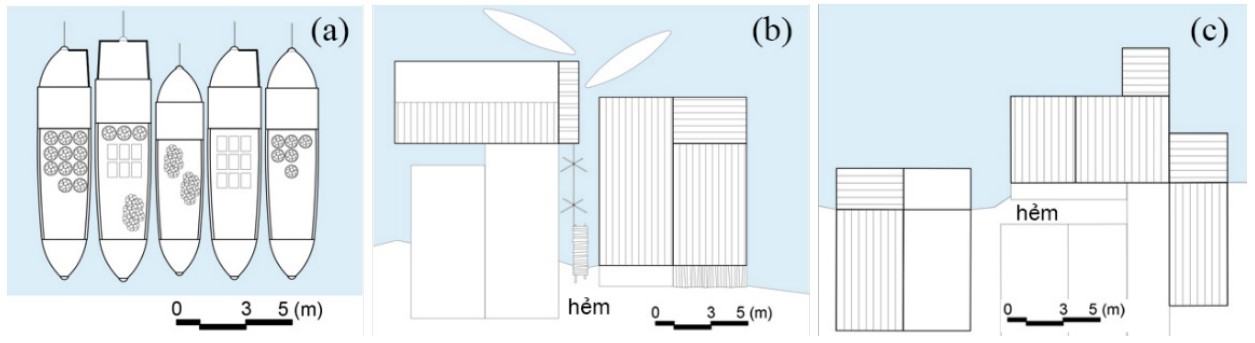

Fig. 7. Three groups of houses along water channels in Mekong Delta (Source: Authors, 2016).

Today, these types of houses are popular at 4/5 places historicaly known for these kinds of settlements in Mekong delta area, including (1) Area of CáiBè floating market TiềnGiang; (2) CáiRăng floating market - CầnThơ; (3)Cà Mau market; (4) floating village in ChâuĐốc - An Giang.

Having similar influencing factors including natural, social-economic conditions, religions and beliefs, these types of settlements also have similar distributions in above four areas:

- Boat houses, houses on stilts, houses with a part on ground and a part on water are popular at all four areas introduced above;

- $\quad$ Floating housesare concentrated more at ChâuĐốc floating village - An Giang, there are also a smaller number at CáiBè and CáiRăng floating markets; it is difficult to find these houses in Cà Mau;

- Houses on ground totally: less popular in these four places. 


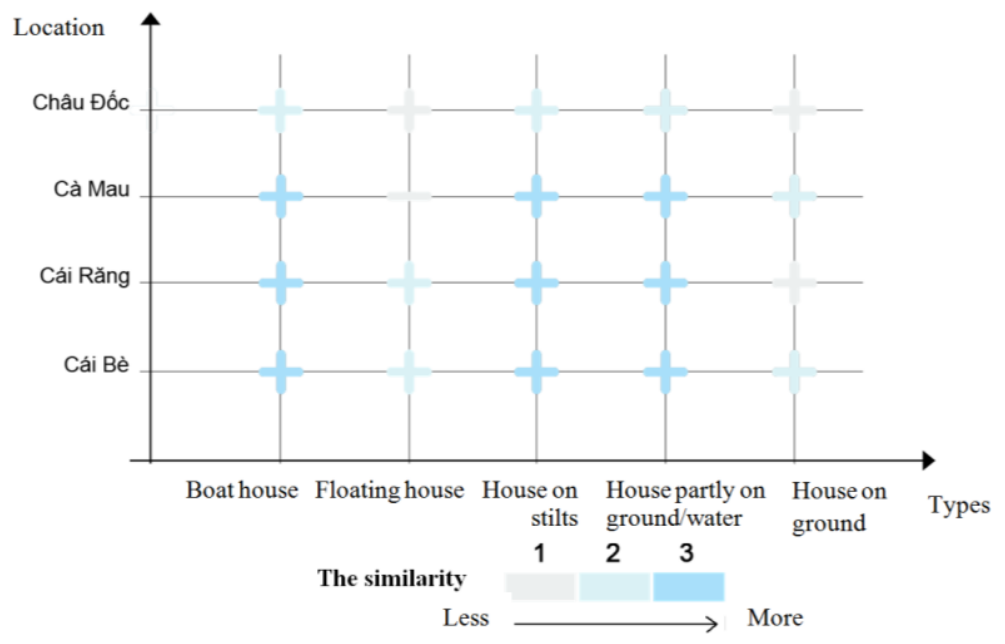

Fig. 8. The similarities of different water-based housing typologies in the four typical places in Mekong Delta (Source: Authors, 2016).

\section{Discussions}

Yet, water-based houses, especially those floating, on stilts are typical corespodents water rise in many places, and for a very long time. Today research on climate change have officially released in Vietnam (2015) [21], predicted that the seas level rises up to $73 \mathrm{~cm}$ to $100 \mathrm{~cm}$ in late $21 \mathrm{st}$ century. Mekong delta is one of the most severed affected with almost $40 \%$ of the entire area; $35 \%$ population would suffer from flood, salinity, and unstable weather conditions; the most vulnerable groups are communities living by water.

People in Mekong Delta have traditionally highly adapted to climatic conditions for a long time, such as seasonal floods (from upstream of Mekong River), salinity, drought, fresh water shortage, and so on. They adjust their houses from the gound/water levels (floating or on stilts), they flexibly combine working, living and trading spaces; their routines have been also adjusdable seasonally and annually [21]. Therefore, climate change adaptations seem having a traditions.

Adaptive principles:

- To respond to not only water-based spatial characteristics of landscape architecture, but also living culture of the communities;

- Understand and evaluate the negative effects of climate change on entire Mekong region, sub-regions, and specific sites/areas/zones, from that to integrate adaptive solutions on urban planning, transport, and building plans and specifications $[22,23]$.

In terms of Planning: to give rooms to the rivers/canals is very strategic, however, also to balance with floating communities and those living along sides with floating houses, stilt houses and half stilts half land houses;

In terms of transport: Water transport should always been popular means of transport, integrated with roads and inland modes, creating quite fascinating images;

In terms of architecture: a part from public buildings which seem manageable by legislations, private houses are more difficult to manage. Typical houses such as houseboats, stilts-houses, houses partly on ground/stilts become rare and only choices of the poor and low income people. Both inner and outer spaces have been diversified based upon needs of the owners who are not necessarily interested in traditions and living culture of their ancestors. 
The life-cycle of these houses are also more temporary which also enable more shorterrenovation/changes.

\section{Conclusions}

Over three centuries of development, from the very first settlements along the water channels and some in the high dry land nearby, people in Mekong delta have conducted selective experiences in creating sustainable living environment which always adapt to natural conditions and social cultures. Settlements based upon distinctive activities which fluently combine living, trading, aquaculturing spaces in one house, normally small house; represented by four typical housing types: Boat house, floating house, house on stilts, half stilts- half land house. Water-based houses are places all kind of living culture to practice daily and occasionally, including living, productivities, and trading of families and households whose lives have been so attached to water. Almost spaces that need communication with the outer environment, meant to face water. Today, these housing typologies have remained popular at floating markets such as Cai Be, Cai Rang, Ca Mau market, and floating Village Chau Doc.

In current context, most of these settlements are under threats of many sources: urbanization, climate change, and social cultural changes of the later generations of residents. This situation requires serious research to find out suitable solutions for the regenerations of these types of houses.

\section{Acknowledgement}

Many thanks to water-based communities in Mekong Delta, especially areas of Cai Be, Cai Rang, Nga Bay floating markets, Ca Mau market, Chau Doc floating fishing village. Their hospitalities and information they share are great sources of references and inputs of the research. Specially thank to University of Architecture Hochiminh City in providing support and enable publications of the research.

\section{References}

1. Q.V. Dương, Identifications of houses on water in Mekong Delta, Vietnam, Master thesis (University of Architecture Hochiminh City, HCMC, 2016)

2. X. T. Vũ, Venacular houses of Southern water land areas, Master thesis on Architecture (University of Architecture Hochiminh City, HCMC, 2004)

3. P. N. Nguyen, Deltaic Urbanism for Living with Flooding in Southern Vietnam, PhD thesis (School of Design Creative Industries Faculty Queensland University of Technology, Queensland, 2015)

4. T.H.H. Vu, Canal-based Houses in Hochiminh City, Issues of Identifications and Respondents to the water-based Distinctive Urban Spatial Values, Conference paper, Houses along canal in Hochiminh city, 11 (2016)

5. T. H. H. Vu, Canals and identity of Saigon - Hochiminh City, PhD thesis (Oxford Brookes University, Oxford, 2010)

6. Q. D. Pham, Finding the Spatial Characteristics of Water-based Urban Landscape in Mekong Delta, Master thesis (University of Architecture Hochiminh city, HCMC, 2004)

7. T. Y. T. Pham, Tangible Culture of Ethnic Communities in Mekong Delta, PhD Thesis on Anthorpology (Institute of Social Science, HCMC, 1992) 
8. T. H. H. Vu, GeoJournal 66-3, 165-186 (2006)

9. URL : http://hoiktstphcm.com/tin-tuc/Tu-Lieu-Tham-Khao-Hoi-Thao-Nha-O-TrenKenh-Rach-Tphom-Thuc-Trang-Giai-Phap-N13389, 17/10/2016 11:25:02 AM

10. Quoc Thang Huynh, Venacular festivals in Southern Vietnam (Culture Institute and Culture- Information Press, Hanoi, 2003)

11. Thi Gam Huynh, Social Economic Transformations of Mekong delta from 175 to 1995 , $\mathrm{PhD}$ Thesis (Social Science and Humanity University, HCMC, 1998)

12. T. H. Nguyen, Urban Planning Journal 3-4, 22- 26 (2003)

13. N. Hung, Floating Market in Mekong delta (Youth publication, HCMC, 2009)

14. Đ. D. Vo, Nguyen Van Tat, Nguyen Huu Thai, Rural Houses in Southern Vietnam (Hochiminh city Press, HCMC, 1984)

15. N. K. Van, Adaptation of Land use and Houses in the upper Mekong Delta's Flooding area (National University of Singapore, 2012)

16. N. T. Tran, Vietnamese culture in Southern West (Hochiminh City Culture-Literature and Arts Publishing House, HCMC, 2013)

17. J.A. LaGro, Site Analysis: A Contextual Approach to Sustainable Land Planning and Site Design (John Wiley \& Sons, Inc., Hoboken, New Jersey, 2008)

18. J.A. Demkin, The Architect's Handbook of Professional Practice, 13th edition (John Wiley \& Sons, Inc., Canada, 2001)

19. S. Unwin, Analysing Architecture (Taylor \& Francis eLibrary, 2003)

20. Thi Hong Hanh Vu, Urban Public Spaces and Housing Morphologies, Lecture Notes, Master Program in Urban Planning and Architecture (University of Architecture Hochiminh City, HCMC)

21. Van Thuong Le, Vu, Thi Hong Hanh, Climate Change Adaptations for cities in Mekong Delta, Ministry research project (Ministry of Construction, Hanoi, 2016) 